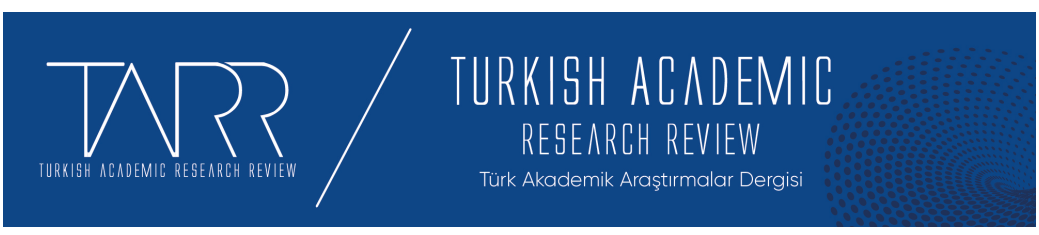

e-ISSN: 2602-2923 Yıl/Year: 2021 Cilt/Volume: 6 Sayı/Issue: 2

\title{
İslam Muhakeme Hukukunda Dava Şartları ve Dava Harcının Bu Bağlamda Değerlendirilmesi
}

Case Conditions in the Islamic Judgement Law and the Evaluation of the Case Fee Regarding to These

\section{Muhammed Selim TOKOĞLU - Zeki YAKA}

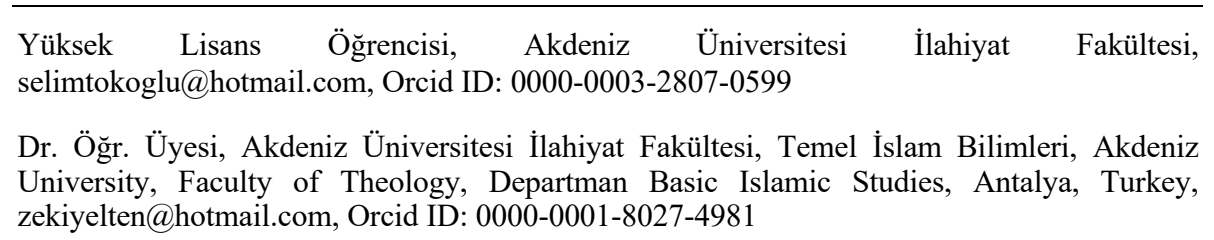

\begin{tabular}{r|l} 
Makale Bilgisi & Article Information \\
Makale Türü - Article Type & Araştırma Makalesi / Research Article \\
Geliş Tarihi - Date Received & 28 Nisan / April 2021 \\
Kabul Tarihi - Date Accepted & 23 Haziran / June 2021 \\
Yayın Tarihi - Date Published & 25 Haziran / June 2021 \\
Yayın Sezonu & Nisan - Mayıs- Haziran \\
Pub Date Season & April - May - June
\end{tabular}

Atıf / Cite as: Tokoğlu, M. S.-Yaka, Z. (2021). İslam Muhakeme Hukukunda Dava Şartları Ve Dava Harcının Bu Bağlamda Değerlendirilmesi/ Case Condıtıons in the Islamic Judgement Law and the Evaluation of the Case Fee Regarding to These. Turkish Academic Research Review, 6 (2), 603-628. Retrieved from https://dergipark.org.tr/tr/pub/tarr/issue/62824/929163

Intihal / Plagiarism: Bu makale, en az iki hakem tarafindan incelenmiş ve intihal içermediği teyit edilmiştir. / This article has been reviewed by at least two referees and confirmed to include no plagiarism. https://dergipark.org.tr/tr/pub/tarr

Copyright (C) Published by Mehmet ŞAHIN Since 2016- Akdeniz University, Faculty of Theology, Antalya, 07058 Turkey. All rights reserved.

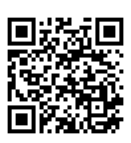

Turkish Academic Research Review - Türk Akademik Araştırmalar Dergisi 


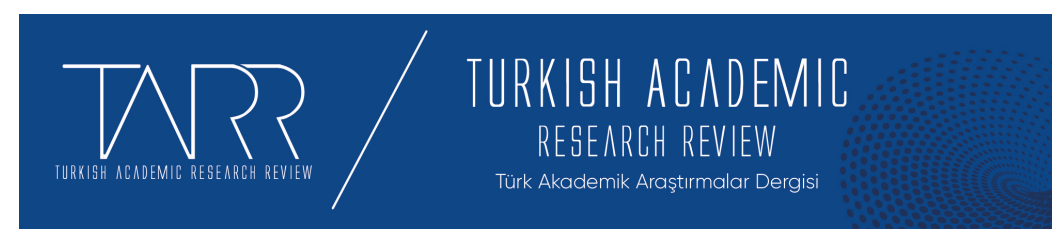

e-ISSN: 2602-2923 Yil/Year: 2021 Cilt/Volume: 6 Sayı/Issue: 2

\title{
İslam Muhakeme Hukukunda Dava Şartları ve Dava Harcının Bu Bağlamda Değerlendirilmesi ${ }^{1}$
}

\author{
Muhammed Selim TOKOĞLU - Zeki YAKA
}

\section{$\ddot{\mathbf{O} z}$}

Toplum düzeninin sağlanması devletin en önemli fonksiyonlarından biridir. Devlet toplum fertleri arasında ortaya çıkan uyuşmazlıkları çözüme kavuşturmak mecburiyetindedir. İnsanlar arasında ortaya çıkan uyuşmazlıklar da ancak herkes tarafindan kabul edilebilir bir merci ile çözüme kavuşabilir. Bu nedenle her devlet toplumuna kaosun hakim olmaması için âdil bir yargı fonksiyonuna ihtiyaç duyar. Yargı insanların haklarını koruduğu gibi kişilerin birbirinin hakkını ihlal etmesini önleyici ve gerektiğinde cezai yaptırım uygulayabilecek bir yapıya sahiptir. İnsanlar uzlaşmaya varamadıkları konularda dava yoluna başvurarak devletten hukuki koruma talep ederler. Şu kadar var ki kişilerin yargı yolunu gereksiz yere meşgul etmelerini önlemek için davalara belli usul şartları tayin edilmiştir. Ancak dava yoluna başvurmak için gerekli olan şartlar yerine geldiği zaman yargı yoluna başvurarak dava açılabilmektedir. İslam muhakeme hukukunda davaların görülebilmesi de belli şartlara bağlanmıştır. Davaların sağlıklı bir şekilde açılıp, kadılar tarafından kabul edilip karara bağlanması için tarafların, mahkemelerin ve dava konusunun gerekli şartları taşıması gerekmektedir. Aksi halde dava kâdı tarafindan kabul edilemez. Bu nedenle davaların kabul edilmesi için hangi şartları taşıması gerektiği büyük önem arz etmektedir. Çalışmamızda öncelikle davanın sıhhat şartlarının neler olduğunu tespit edeceğiz. Diğer taraftan davaların kâdılar tarafından kabulü için dava harcının dava şartları arasında olup olmadığının tespitine çalışacağız. İslam yargı prensipleri kâdılarla doğrudan bağlantılı bir yapıya sahip olduğu için dava harcı yatırılması meselesi kâdıların mesleğinden ötürü maaş alıp alamayacağı ve kişilerin arasındaki çekişmeyi sonlandırmak için kişilerden ücret talep edip edemeyecekleri konularıyla ilişkilidir. Eserlerde dava harcı konusuna müstakil olarak değinilmemiştir. Bu nedenle dava harcı konusunu kâdının ücret alması ile ilişkilendirip dava şartları arasında sayılıp sayılmadığını tespit etmeye çalışacağız.

Anahtar Kelimeler: Dava Harcı, Kâdıların Maaşı, Dava Şartları, Davacı, Davalı

\section{Case Conditions in the Islamic Judgement Law and the Evaluation of the Case Fee Regarding to These}

\begin{abstract}
Ensuring social order is one of the most important functions of the state since human being. The state is obliged to resolve disagreements that arise or could arise between individuals of the main people. Conflicts that arise between people can only be resolved with an authority that is accepted by everyone that are present in the society. For this reason, every state needs a fair judicial function so that chaos does
\end{abstract}

1 Bu makale, "İslam Hukukunda Davanın Sihhat Şartlarl” isimli 2020 yılında Akdeniz Üniversitesi Sosyal Bilimler Enstitüsünde tamamlanmış Yüksek Lisans Tezinden türetilmiştir.

Turkish Academic Research Review - Türk Akademik Araştırmalar Dergisi 
not rule over its society. As the judgement protects people's rights, it has a structure that prevents individuals from violating each other's rights and can impose vindictive sanctions when necessary in its situation. People can seek legal protection from the state by having recourse to litigation in matters that they cannot reach an agreement on. However, certain procedural conditions have been assigned to cases in order to prevent individuals from unnecessarily occupying the judicial path when needed. But on the other hand, a lawsuit only can be brought by having recourse to a judicial path when the conditions required to apply for a lawsuit are carried out completely. In the Islamic judgement law, as well the ability to hear the cases is bounded to certain conditions. It is necessary that the parties, the courts and the case matter carry essential conditions in order to get cases expressed healthy, accepted and resolved by the determined judges. Otherwise the case will not be accepted by the judge. For this reason, it is of great importance what conditions the cases must meet in order to be accepted. In our study, we will first determine what the health conditions of the case are in order to be accepted. On the other hand there is tried to determine the existence of the case fee among the lawsuit conditions in order to the acceptance of the cases by judges. Because the Islamic juridical principles have a directly linked structure with judges, the case fee payment issue is related with the matter of the allowance of judges earning their salary on account of their job and the allowance of demanding the case fee to terminate the conflict between people. There is not been touched on this case fee issue separately in other works. For this reason, we will try to associate the case fee issue with the fee acceptance of a judge and determine whether it is considered among the health conditions of the case.

Keywords: Case fee, Salary of Judges, Lawsuit Conditions, Claimant, Respondent

\section{Structure Abstract}

People have very different characteristics from each other in terms of their differentiating natures. This situation causes conflicts between people in the ordinary course of life. These disagreements arise from the violation of some rights granted to people by the legal order by others. In such situations, people need an authority that can and will solve their problems. If people tried to solve their problems by using their own methods, as stated in the hadith-i sharif: "If people were given what they wanted (just because of their claims), people would demand the blood and property of others. However, the oath belongs to the defendant." there would be a chaos in the society that would be difficult to resist after that moment. For this reason, Islamic law regards the way of being able to litigate in order to resolve the conflicts that arise between people in cases of disagreement. Conflicts of individuals during disagreements are terminated through the judicial power used by the state. This situation reveals the importance of the judiciary in order to increase the welfare and peace level of the society. In the Islamic judicial law, the trial of cases is bound by certain procedural rules for the most fair results. These rules of procedure differ depending on whether it is a civil or criminal case. If the rules of procedure are not been followed than this will result in many shortcomings. For example, if there occurs a failure in complying with the procedural rules in a criminal case than this will result in the wrongful punishment of the accused, and also the right will then be delivered to the wrong person in civil cases. For this reason, the Islamic judgment procedure is of vital importance for the realization of justice. One of the most important elements for the judgment procedure is the health conditions of the case. In our study, we will try to determine the health conditions of the case, which is of great importance to ensure justice among individuals, and to examine the status of the case fees in terms of the Islamic legal judgment procedure. In Islamic law of procedure, certain procedural rules are stipulated in order to hear and decide the cases. These rules are vital for the fair trial and resolution of cases. The parties must meet certain procedural requirements of the subject of the case and 
the court. Persons must have the capacity to be a party and litigation in order to sue and dispose of the case they have opened. It is the fact that individuals do not have to hold a proxy in cases. But in cases followed by a proxy, it is necessary to submit a valid attorney. It is necessary that the person has the title of being a party. The directing of the case to a specific person and the presence of the defendant during the case, except in exceptional circumstances, is necessary. The statements of the plaintiff must be precise and consistent concerning the advantage of the case in the context of the fact that the subject of the case is legitimate and controversial. The subject of the lawsuit must be something mentally, customarily possible and known. A judge whose duty is limited by the caliph has to deal only with the matters falling within the scope of his duty and to hear the cases in the council of judges. It cannot be ignored that the parties, the subject matter of the case and the conditions of the court case are indispensable conditions for the trial of the case. However, among these conditions, there was no case condition such as depositing the lawsuit fee in the classical fiqh books. Since this issue is directly related to the judges, the subject of the litigation fee can be examined in relation to the salaries of the judges and demanding wages. In this context, it can be concluded that paying a fee to file a lawsuit is not considered among the health conditions of the case, while even the salary of the judges is a controversial issue in Islamic law of procedure. However, an open door is left for the state to order the litigation fee if it is unable to meet the legal costs. In Islamic law, it can be said that paying a lawsuit fee to file a lawsuit is not considered among the health conditions of the lawsuit, and it can be said that it is more preferable not to be charged for the lawsuit.

\section{Giriş}

İnsanlar yapıları açısından birbirinden çok farklı özelliklere sahiptirler. $\mathrm{Bu}$ durum hayatın olağan akışında kişiler arasında uyuşmazlıkların çıkmasına sebep olmaktadır. $\mathrm{Bu}$ uyuşmazlıklar hukuk düzenince insanlara tanınan bazı hakların başkaları tarafından ihlal edilmesinden kaynaklanmaktadır. Bu tür durumlarda insanlar problemlerini çözebilecek bir merciye ihtiyaç duyarlar. Eğer kişiler sorunlarını kendi yöntemlerini kullanarak çözmeye kalkışsalardı, "Ínsanlara (sırf) iddiaları sebebiyle istedikleri verilseydi insanlar başkalarının kanlarını ve mallarını talep edeceklerdi. Lakin yemin davalıya aittir. ${ }^{2}$ " hadisinde işaret edildiği üzere toplumda baş edilmesi güç bir kaos meydana gelirdi. Bu nedenle İslam hukuku insanlar arasında ortaya çıkan çekişmelerin çözüme kavuşturulması için dava yolunu meşru görmüş; anlaşmazlıkların devlet tarafından kullanılan yargı yoluyla sonlandırılması teşvik edilmiştir. Söz konusu durum toplumun refah ve huzur seviyesinin artması için yargının önemini ortaya çıkarmaktadır. İslam muhakeme hukukunda davaların görülmesi en âdil sonuçlar için belli usul kurallarına bağlanmıştır. Bu usul kuralları hukuk veya ceza davası olmasına göre farklılık arz etmektedir. Usul kurallarına uymamak birçok eksikliklere neden olacaktır. Söz gelimi ceza davasında usul kurallarına uymamak sanığın yanlış cezaya çarptırılması,

2 Ebu'l-Hüseyn Müslim b. el-Haccâc Müslim, el-Câmi 'u's-sahîh, (thk. Muhammed Fuâd Abdulbâkî), Beyrut, Dâru İhyâi't-Turâs, ty., “Akdiyye”, no:1711.

Turkish Academic Research Review - Türk Akademik Araştırmalar Dergisi 
606 İslam Muhakeme Hukukunda Dava Şartları Ve Dava Harcının Bu Bağlamda Değerlendirilmesi

hukuk davalarında ise yanlış kişiye hakkın teslim edilmesi sonucunu doğuracaktır. $\mathrm{Bu}$ nedenle adaletin gerçekleşmesi için İslam muhakeme usulü hayati önem taşımaktadır. Muhakeme usulü için önemli unsurlardan biri de davanın sıhhat şartlarıdır. Çalışmamızda kişiler arasında adaletin sağlanması için büyük önem arz eden davanın sıhhat şartlarını tespit edip İslam hukuk muhakeme usulü açısından dava harçlarının durumunu ortaya koyacağız.

\section{A. DAVANIN SIHHAT ŞARTLARI}

Kadim fikıh geleneği içinde alimler ilk dönemden itibaren "Kitâbü'dDâvâ" bölümlerinde tüm detayları ile konuyu işlemişlerdir. Ayrı başlık altında ele alınmasa da söz konusu şartlar ve ayrıntıları fıkıh kitaplarında yerini almıştır. İslam hukukunda geçerli/meşru bir dava için işaret edilen başlıca şartlar şunlardır.

\section{Davada Ehliyet Şartı}

Ehliyet: Lügatte; liyâkat, hak etme, yeterlilik manalarına gelmektedir. ${ }^{3}$ Istılahta ise; bir kişinin, kanun koyucunun hitabına muhatap olabilme sıfatını ifade eder. ${ }^{4}$ Ehliyet; vücub ve eda ehliyeti olmak üzere iki kısma ayrılmaktadır.

Bir kimsenin insan olmasından dolayı sahip olduğu ehliyete vücub ehliyeti denir. Kişinin lehinde veya aleyhinde olan hakların sabit olması durumunu ifade eder. Ehliyetin bu türünde kişinin yaşının, aklının, reşit olmasının bir önemi yoktur. Kişinin sağ olarak doğması onun bu ehliyete sahip olması için yeterlidir. Annesinin karnında olan çocuklar daha tam ve sağ doğumla dünyaya gelmedikleri için nâkıs vücub ehliyetine sahiptirler. Sağ olarak doğan herkes tam vücub ehliyetine sahiptir. ${ }^{5}$

Fiilleri yapmak ve onların neticelerine katlanmak hususunda şeriatin amellerine itibar ettiği kimsenin sahip olduğu ehliyete eda ehliyeti denir. ${ }^{6}$ Şeriat tarafından kişinin bu ehliyete sahip olması için yaptığı fiili ve neticelerini anlayabilecek akla ve hisse sahip olması şart koşulmuştur. Aklı kâmil olanlarda tam eda ehliyeti bulunmaktadır. Bazı kimselerde semavi veya müktesep ârızalardan kaynaklanan aklî melekelerine etki eden durumlar söz konusu olabilir. Bu

Fîrûzâbâdî, Ebu't-Tâhîr Mecduddîn Muhammed b. Yâkup, el-Kâmûsu'l-muhît, (thk. Muhammed Naim Araksûsi), Müessetu'r-Risâle, Beyrut, 2005, s. 963.

4 Arcânî, Abdullah b. Nâsır, Şurûtu etrâfi'd-d'avâ fi'l-fikhi ve nizâmi 'l-murâfa 'ât, Nâif Arap Üniversitesi Eğitim Fakültesi, Riyad, 2006, s. 79.

5 Kutluboğa, Ebu'l-Fedâ Zeynuddin Kâsım, Hulâsatu'l-efkâr şerhu muhtasari'l-menâr, (thk. Hafiz Senâullah Zâhidî), Dâru İbni Hazm, yy., 2003, s. 179; Arcânî, Surûtu etrâfi'dd'avâ, s. 80.

6 Cüdey, Abdullah b. Yusuf b. İsa, Teysîru ilmi usuli'l-fikh, Müessesetu'r-Reyyân, BeyrutLübnan, 1997, s. 85; Arcânî, Şurûtu etrâfi'd-d'avâ, s. 79. 
durumdaki kimselerin yaptığı bütün tasarruflar geçerli değildir. Bu nedenle nâkıs eda ehliyetine sahiptirler. ${ }^{7}$

Taraf ehliyeti: Yapılan tarifler bağlamında kişilerin davada taraf olarak kabul görmesi için vücub ehliyetine sahip olması gerekir. Ölen kimselerin şahsına sıkı sıkıya bağlı olan haklarda leh veya aleyhlerine dava açılamaz. Çünkü bu kimseler ölüm ile vücub ehliyetlerini kaybetmişlerdir. Böylelikle davada taraf olma ehliyetleri de kaybolmuştur. Fakat ölenin malvarlığı ile ilgili olan davaların, mirasçılarına veya terekeye karşı açılması mümkündür. ${ }^{8}$

Dava ehliyeti: Bir kimsenin kendi adına veya yerine temsilcisinin davayı yürütebilme ehliyetine "dava ehliyeti" denir. Kâmil eda ehliyetine sahip olan bir kimse dava ehliyetine de sahiptir. ${ }^{9}$ Kişilerin dava açmaları ve açtıkları davada tasarrufta bulunmaları için eda ehliyeti olması gerekir. Eda ehliyeti olmayan bir kimse tasarrufta bulunamaz. Onun yerine adına tasarrufta bulunabilecek olan kimseler tayin edilmesi gerekir. Çocukluk, kölelik veya delilik gibi sebeplerden dolayı tasarrufları kısıtlı bulunan kişilerin mallarında tasarruf etmelerinin yasak olduğu konusunda âlimler ittifak etmiştir. Çocuğun tasarrufu velisinin, kölenin tasarrufu ise efendisinin iznine bağlanmıştır. ${ }^{10} \mathrm{Bu}$ sebeple kişilerin davada taraf olabilmeleri için taraf ve davalarını yürütebilmeleri için dava ehliyetine sahip olmaları davanın sıhhat şartı olarak görülmüştür.

\section{Davada Temsil Durumu}

Dava ehliyeti olmayan kimselerin davada veli ya da vasîleri tarafindan, gerçek kişiliğe sahip olmayan tüzel kişilerin ise yetkili organları ya da kayyım, emin gibi sıfatları taşıyan devletin görevlendirdiği kimseler tarafından temsil edilmesine "kanuni temsil" denir. ${ }^{11}$ Küçük çocukların kendileri hakkında yaptıkları tasarruflar geçersiz olmasından dolayı çocuklar, onlar adına haklarını koruyabilecek ve haklarında tasarruf edebilecek birine ihtiyaç duyarlar. Bu kimseler çocuklar adına

Cüdey, Teysîru ilmi usuli'l-fikh, s.85; Arcânî, Surûtu etrâfi'd-d'avâ, s. 79.

8 Atar, İslam Yargllama Hukukunun Esaslarl, M.Ü. İlahiyat Fakültesi Yayınları, İstanbul, 2019, s. 195.

$9 \quad$ Atar, İslam Yargılama Hukukunun Esaslarl, s. 196.

10 İbn Hubeyra, el- Vezir Yahya b. Muhammed Avnuddîn Ebu'l-Muzaffer, İcmâ'u'le'immeti'l-erba 'ati ve ihtilâfihim, (thk. Muhammed Hüseyin), Dâru'l-Ulâ, 2009, c.II, s. 450; Arcânî, Surûtu etrâfi'd-d'avâ, s. 80.

11 Atar, İslam Yargılama Hukukunun Esasları, s. 197.

Turkish Academic Research Review - Türk Akademik Araştırmalar Dergisi https://dergipark.org.tr/tr/pub/tarr 
608 İslam Muhakeme Hukukunda Dava Şartları Ve Dava Harcının Bu Bağlamda Değerlendirilmesi

tasarrufta bulunabilecek veya çocukların muhtemel tasarruflarına izin verme yetkisine sahip olabilecek veli ya da vasîleridir. ${ }^{12}$ Sonuç olarak çocuklar velisi varsa davalarda velisi tarafindan temsil edilir. Velisi yoksa bu takdirde ya velisinin tayin ettiği bir vasî tarafından ya da veli bir tayinde bulunmadıysa kâdı tarafindan belirlenen bir vasî tarafından temsil edilir.

Kişiler dava ve işlerini kendi takip edebileceği gibi dava ehliyeti olan herkesi, dava işlerini takip etmesi için vekil tayin edebilirler. Vekil bu işlemi ücret karşılığında veya herhangi bir bedel almadan da yapabilir. Kişinin kanuni bir zorunluluk olmadan kendi yerine dava işlerini yürütmesi için vekil tayin etmesine "iradî temsil” denilir. ${ }^{13}$ Kişilerin davalarda temsil edilebilmesi için mutlaka geçerli bir vekâletnameleri olmalıdır.

İnsanın kendi yerine başkasını vekil kılabildiği tüm durumlarda, davada da başkasını vekil kılması mümkündür. ${ }^{14}$ Hastalık, sefer gibi özür sayılabilecek hallerde başkasına davayı takip etmesi için vekâlet vermesi konusunda ittifak vardır. Fakat fakihler herhangi bir özrü olmayan kimsenin vekâlet vermesi hakkında ihtilaf etmişlerdir. ${ }^{15}$ Cumhur-u ulema karşı tarafın rızasına bakmaksızın ve özürsüz olarak kişilerin davada kendilerini temsil etmesi için vekil tayin edebileceğini söylerken İmam-ı Azam ancak karşı tarafın rızasını alarak özürsüz vekil tayin edilebileceği görüşünü benimsemiştir. ${ }^{16}$

Netice itibari ile İslam muhakeme usulünde davalarda bizzat davacının kendisinin temsil zorunluluğu davanın sıhhat şartları arasında sayılmamıştır. Kişiler davalarını kendisi takip edebileceği gibi kendilerini temsil etmesi için başkalarını da tayin edebilir. Ancak başkasının vekil kılınarak takip edildiği davalarda geçerli bir vekâletnamenin kâdıya sunulması davanın sıhhat şartları arasında sayılmıştır.

\section{Taraf Sifatı}

12 Semnâni, Ebu'l-Kasım Ali b. Muhammed, Ravdatu'l-kudât ve tarîkun-necât, (thk. Salahaddin en-Nâhî), Müessesetu'r-Risâle, Beyrut, 1414, c. I, s. 179.

13 Atar, İslam Yargilama Hukukunun Esaslarl, s. 197.

14 Kahtân, Usâme b. Said vd., Mevsû 'atu'l-icmâ 'i fi 'l-fikhi'l-íslâm, Dâru'l-Fadîle, Riyad, 2012, c. IV, s. 340; İbn Hubeyra, İcmâ, c. II, s. 32.

15 Sadru'ş-Șehîd, Husameddin Ömer b. Abdulaziz, Serhu edebi'l-kâdî li'l-Hassâf, (nşr. İrşad Matbaasi), Dâru'l-Arabiyye, Bağdad,c. III, s. 404.

16 Kâsânî, Alaaddin Ebu Bekir b. Mesud, Bedâ'i'us'sanâ'i fî tertîbi's-serâ'i, (thk. Muhammed Têmir), Dâru'l-Hadis, Kahire, 2005, c. VIII, s. 414; İbn Ferhûn, İbrahim b. Muhammed, Tabsiratu'l-hukkâm fî usûli'l-akdlyye ve menehicu'l-ahkâm, Dâru 'Âlemi'lKütüb, Riyâd, ty, c. I, s. 111 
Husumet çekişme, uyuşmazlık, mücadele, davalaşma manalarına gelmektedir. ${ }^{17}$ Herhangi bir konuda uyuşmazlığın olduğu kimseye ve davada husumetin yöneltildiği kişiye hasım denilir. ${ }^{18}$ Hasmın kim olduğunu tespit etmek ise taraf sıfatını ifade eder. Bu nedenle dava konusunun gerçekten alakalı kimseye yöneltilmesi büyük önem taşır. Aksi takdirde dava, taraf sıfatı yokluğu sebebiyle dinlenilemez. Davacı ve davalıdan her birinin davada taraf sıfatı olması şart koşulur. Aynı zamanda davanın etrafında döneceği hüküm veya olay ile ilgili bir bağlantılarının olması, şeriatın onlardan her biri için bu sıfatı alabilmelerine olanak tanıması (davacıya, iddia ve talep etme hakkı vermesi, davalıyı ise cevap vermek konusunda mükellef kılması gibi.) gerekir. ${ }^{19}$ Davada taraf sıfatı faklı hallerde görülebilir;

a. Davacı kendi hakkını talep eden kişi sıfatıyla davada bulunabilir. ${ }^{20}$ Kişinin bizzat kendi hakkını talep etmesi konusunda herhangi bir ihtilaf söz konusu değildir.

b. Davacı başkasını temsil etme sıfatıyla davada bulunabilir. ${ }^{21}$ Davacı, veli, vasî, kayyım, vekil, tüzel kişilerde mütevelli gibi başkasının yerine geçerek başkasına ait olan bir hakkı talep eden sıfatıyla dava açabilir. Asilin yerine geçme sıfatını aldığı davalarda davanın sonucu asile döner. ${ }^{22}$

c. Alacaklı borçlunun hakkını muhafaza etmek için onun yerine dava açan konumunda olabilir. ${ }^{23}$ Burada alacaklının kendi menfaatini korumak için borçlunun mal varlığına el konulmasına engel olması söz konusudur.

d. Kamu yararına birden fazla kişiye zararı dokunması sebebiyle menfaati kendilerine dönecek olan kişiler, davada toplu bir şekilde davacı olabilecekleri gibi bazı insanlar topluluğun yerine geçerek onlar adına da dava açabilirler. ${ }^{24}$

Davanın doğru kişiye yöneltilmesi davanın vazgeçilmez unsurlarındandır. $\mathrm{Bu}$ nedenle davada kişilerin taraf sıfatına sahip olmaları kazâî

17 İbn Seyda, Ebu'l-Hasan Ali b. İsmail, el-Muhassas, Dâru İhyâu't-Turâs, Beyrut, 1996,c. III, s. 407.

18 Râzi, Ebu Bekir Zeynuddîn ebu Abdullah b. Muhammmed, Muhtâru's-sıhâh, (thk. Yusuf Şeyh Muhammed), Mektebutu'l-Asriyye, Beyrut, 1999,s. 91.

19 Arcânî, Şurûtu etrâfi'd-d'avâ, s. 117.

20 İbn Ferhûn, Tabsiratu'l-hukkâm,c .I, s. 116; Tarablûsî, Ebu'l-Hasan Alaaddin, Mu 'înu'lhukkâm fi me yeteraddedu beyne'l-hasmeyni mine'l-ahkâm, Dâru'l-Fikr, yy.,ty., s. 62.

21 Yâsîn, Muhammed Naim, Nazariyeti't-d'avâ beyne Şeri'ati'l-İslamiyye, Dâru Alemi'lKütüb, Kingdom yay., Riyad, 2003, s. 280.

22 Nasr Ferid Vâsıl, Nazariyyetu'd-d'avâ ve'l-ispât fi'l-fikhi'l-íslâmi, Dâru'ş-Şurûk, Kahire, 2002, s. 13-14; Beyâtî, Abdulgafûr Muhammed, el-Kavâ 'idu'l fikhiyye fi'l-kadâ, Dâru'lKütübü'l-İlmiyye, Beyrut, 2015, s. 216.

23 Yâsîn, Nazariyyetu'd-d 'avâ, s. 280

24 Yâsîn, Nazariyetu'd-d'avâ, s. 282.

Turkish Academic Research Review - Türk Akademik Araştırmalar Dergisi 
610 İslam Muhakeme Hukukunda Dava Şartları Ve Dava Harcının Bu Bağlamda Değerlendirilmesi

adalet açısından büyük önem arz etmektedir. Bu nedenle İslam muhakeme usulünde taraf sıfatı davanın sıhhat şartları arasında sayılmıştır.

\section{Davalının Tespiti}

Davanın taraflarından biri olan davacının belli bir kimse olması gerekir. Âlimler eserlerinde davacının belli olmasını ayrı bir şart olarak zikretmemişlerdir. $\mathrm{Bu}$ şart onların zımnî ifadelerinden anlaşılmaktadır. Çünkü davanın açılması davacının kâdının huzuruna gelip davayı söylemesiyle mümkündür. $\mathrm{Bu}$ nedenle davacının belli olmaması gibi bir durum söz konusu değildir. ${ }^{25}$ Taraf sıfatı davalarda iddianın gerçekten alakalı kişiye yöneltilip yöneltilmediğinin tespitini yaparken davalının tespiti iddianın yöneltildiği kişinin kim olduğunu belirler.

Davaların faydası, insanların ihlal edilen haklarını onlara geri vermektir. $\mathrm{Bu}$ nedenle bir davada davacıya hakkını teslim edebilmek için hasmın yani davalının belli olması gerekir. Davalar, davalıyı ilzam etmek ve hüküm sebeplerinden biri ile dava sabit olduğu zaman hüküm vermek içindir. Bu nedenle davalının bilinmediği bir dava sahih olmaz. ${ }^{26}$ Mecelle'de bu şart, "Davalının malum olması gerekir. Binaenaleyh davacı, tayin etmeksizin benim filan köy ehlinden birinde veya bazı insanlarda alacă̆ım var dese davası sahih değildir. Davacının davalıyı belirlemesi gerekir. ${ }^{27 "}$ şeklinde kanunlaştırılmıştır. Davanın sahih olabilmesi için davanın müşahhas bir kişiye veya birden fazla kişiye yöneltilmesi gerekir.

Davacının davalının ismini bilmesi şart koşulmamıştır. Davacı davalının ismini bilmediği zaman davası bâtıl olmaz. Aynı şekilde davalının bir kişi olması da şart koşulmamıştır. Davalı birden fazla kişi de olabilir. ${ }^{28}$ Burada önemli olan husus davanın muayyen bir kimseye ve kimselere yöneltilmesidir. $\mathrm{Bu}$ nedenle İslam muhakeme usulünde davalının belli olması davanın sıhhat şartları arasında sayılmıştır.

\section{Tarafların Hazır Bulunması}

Dava esnasında tarafların davada hazır bulunması gerekir. Davacının hazır bulunmasını âlimler açıç̧a dava şartları içerisinde saymamıştır. Bunun nedeni davacı, hâkimin huzuruna gelmeden davanın açılmasının mümkün olmamasıdır.

25 Heytemî, Şihâbuddin Ahmed b. Hacer, Tuhfetu'l-muhtâç fi şerhi'l-Minhâç, Dâr-u İhyâ'utTurâs, Beyrut, ty, c. X, s. 293.

26 Cessâs, Ebu Bekir Ahmed b. Ali er-Râzi, Şerhu edebu'l-kâdî, Amerika Üniversitesi, Kâhire, 1977, s. 406; Ali Haydâr Hoca Emin Efendi, Dureru'l-hukkâm fi șerhi Mecelleti'l ahkâm, (terc. Fehmi Hüseyin), Dâru'l-Ceyl,1991, ,c. IV, s. 181.

27 Mecelle md. 1617.

28 Ayrıntılı bilgi için mecelle madde 1644'e bk., Ali Haydâr, Dureru'l-hukkâm,c. IV, s. 181. 
Fakat her ne kadar söylemeye ihtiyaç olmasa da fakihlerin ibarelerinin mefhumlarından davacının da dava esnasında hazır bulunmasının bir dava şartı olduğu anlaşılmaktadır. Tarafların hazır bulunmasından davalının hazır bulunması anlaşılmalıdır. $^{29}$

Âyet-i kerimede "Aralarındaki anlaşmazlıkları çözüme bağlasın diye Allah'a ve resulüne çağrıldıklarında müminlerin sözü, "Dinledik ve boyun ĕgdik" demekten ibarettir. İşte kurtuluşa erenler de bunlardır! ${ }^{30}$ " buyrulmaktadır. Davalının, bu âyet-i kerimenin gereği ile amel ederek mahkemeye çağrıldığı zaman icabet etmesi gerekir. Aksi halde herhangi bir mazereti olmadan davete icabet etmeyen davalı, zalim ve günahkâr olur. ${ }^{31}$ Fakihler, hüküm meclisinde olmayıp beldede bulunan davalının mahkemede hazır bulunması gerektiği görüşünde ittifak etmişlerdir. Fakat mahcur, hapiste olan, kendisinden haber alınamayan gibi farklı durumlarda mesafeye bakmamışlardır. ${ }^{32}$ Fakihler gaip hakkında davacının delil ve iddiasının dinlenmesi konusunda ittifak etmişlerdir. Fakat bu delil ve iddiaya dayanarak gaip hakkında hüküm verilmesi konusunda ihtilaf edilmiştir. ${ }^{33}$

İmam-1 Azam Ebu Hanife (ö.150), davanın kabulünden sonra davalının bulunmasını şart koşmuştur. Ona göre dava esnasında davalı hazır bulunmazsa o dava dinlenilmez; davalı davada hazır bulunana kadar hakkında hüküm verilemez. Hanefilerde gaip üzerine hükmedilmediği gibi dava sırasında hazır bulunmayan davalıya karşı da dava kabul edilmez. Gaip davalının şehadetten önce veya sonra gaip olması ya da kâdının meclisinde bulunmaması veya kâdının bulunduğu beldede olmaması arasında bir fark yoktur. Bu şart Hanefi mezhebi dışındaki mezheplerde yoktur. ${ }^{34}$ Malikiler'den İbn Mâcişûn (ö.212), bir rivayette Ahmed bin Hanbel (ö.241), İbn Ebî Leyla (ö.148) ve Sevrî’nin (ö.161) de bu görüşte olduğu nakledilmektedir. ${ }^{35}$

Davalının kendisinin veya yerine vekilinin, vasîsinin, velisinin ya da mütevellinin, hüküm, şehâdet ve dava zamanında hazır bulunması şart koşulmuştur.

9 Arcânî, Şurûtu etrâfi'd-d'avâ, s. 185.

Nur, 24/51.

31 İbn Kesîr, Ebu'l-Fedâ İsmail el-Kuraşî, Tefsîru'l-Kur-âni’l-Azîm, (thk. Muhammed Hüseyin Şemseddin), Dâru'l-Kütübü'l-İlmiyye, Beyrut, 1419, c. VI, s. 68.

32 Şirbîni, Şemseddin Muhammed b. Ahmed el-Hatîp, Muğni'l-muhtâç ile Mâ'rifeti me'âni elfâzu'l-Minhâç, Dâru'l-Kütübü'l-İlmiyye, 1994, c. VI, s. 320; İbn Müflih, Muhammed b. Müflih, Ebu Abdullah, el-Furû, Menâr, Misir, 1339, c. III, s. 828.

33 İbn Hubeyra, İcmâ, c. II, s. 417.

34 Tayyar, Abdullah b. Muhammed, Flkhu'l-müyessere, Medâru'l-Vatan, Riyad, 2011, c. VIII, s. 98; Zuhayli, Vehbe, Mevsû'atu'l-fikhi'l-İslâmî ve'l-kadâye'l-mu 'âsıra, Dâru'lFikr, Beyrut, 2013, c. VI, s. 434.

35 Muhammed Rafet Osman, Nizâmu'l-kadâ fi'l-fikhi'l-İslâm, Dâru'l-Beyan, yy., 1994, s. 222; İbn Hubeyra, İcmâ, c. II, s. 417.

Turkish Academic Research Review - Türk Akademik Araştırmalar Dergisi 
612 İslam Muhakeme Hukukunda Dava Şartları Ve Dava Harcının Bu Bağlamda Değerlendirilmesi

Davada hüküm, davalının ikrarına ya da delil sunmasına göre farklılık gösterir. İkrar veya delile göre hüküm, ancak davalının hazır olması ile mümkün olur. Davalı mahkemede hazır olmadığı müddetçe davacının delili ve davası hakkında hüküm verilmez. Şayet kâdı, davacının delilini davalı hazır olmadan dinlese hakkında hüküm verse davalı davada hazır oluncaya kadar verdiği hüküm yürürlüğe girmez. Verilen hüküm ister Allah hakkı olsun ister kul hakkı olsun davalının duruşmada hazır bulunması şart koşulmuştur. ${ }^{36}$

Dava ile arasında bağlantı bulunan vasî, mirasçı, vekil, mana itibari ile hazır olan davalı hükmündedir. Vekil ve vasî apaçık izinle davalının yerine geçmiştirler. Mirasçı ise şer’i anlamda davalının yerine geçmiştir. Bu nedenle sayılan kimselerin davada hazır bulunması ayn davalının kendisinin davada hazır bulunması gibidir. Bu yüzden bunlar hakkında hükmetmek gaip hakkında hüküm değildir. ${ }^{37}$ Verilen bilgiler 1şı̆̆ında İslâm muhakeme usulünde davanın sıhhat şartlarından birinin de dava esnasında davalının hazır bulunması olduğu anlaşılmaktadır.

\section{Davacının İfadeleri}

Hak sahibinin hakkını almak için kesin ifadeler kullanması ve kendine hakkı kesin bir şekilde izafe etmesi davada şart koşulur. Örneğin davacı, "zannediyorum" veya "öyle saniyorum" veya "bu filana aittir" gibi kesin olmayan, belirsiz ibareler kullanması halinde dava dinlenilmez. Fakat bu şart ceza davalarında istisna edilmiştir. ${ }^{38}$ Davada davacının davalıdan hakkını talep ettiğini zikretmesi, kâdıdan davalının mahkemede hazır bulundurulmasını ve davalının cevap vermesini istemesi şart koşulur. ${ }^{39}$ Çünkü insanın hakkını vermek talep ile olur. ${ }^{40}$ Başkasının elinde bulunan bir mal o şahsa rehin olarak verilmiş veya elinde para karşıllı̆̆

Ali Haydâr, Dureru'l-hukkâm, c. IV, s. 182.

37 Kâsânî, Bedâi, c. VIII, s. 416; Serahsi, Ahmed b. Ebi Sehl Şemsu'l-Eimme, el-Mebsut, Dâru'l-Mârife, Beyrut, 1993, c. XVII, s. 39; Ebu'l-Ferec, Abdurrahman b. Muhammed b. Ahmed b. Kudâme el- Makdisî, Şerhu'l-Kebîr ale metni'l-Muknî, Dâru'l-Kütübü'lArabiyye, yy, ty, c. XXVIII, s. 524; Ali Haydar, Dureru'l-hukkâm, c. IV, s. 182.

38 İbn Desûkî, Muhammed b. Ahmed, Hâşiyetu't-Desûkî ale'ş-şerhi'l-Kebîr, Dâru'l-Fikr, yy., ty., c. 4, s. 144; Nizâmuddîn Belhî vd., Fetâvâyı hindiyye, Dâru'l-Fikr, BeyrutLübnan, 2009, c. IV, s. 5; Tayyar, Flkhu'l-müyessere, c. VIII, s. 100.

39 Tayyar, Flkhu'l-müyessere,c. VIII, s. 100.

40 Kâsânî, Bedâi,c. VIII, s. 414. 
hapsedilmiş olabilir. İşte bu nedenlerden dolayı davacının hakkı talep etmesi gerekir. Çünkü davacının hakkını talep etmesi bu ihtimalleri ortadan kaldırır. ${ }^{41}$

Davada tenâkuz bulunmaması davanın sıhhat şartlarından biridir. ${ }^{42} \mathrm{Bu}$ sebeple davacının sözleri/talepleri arasında tenâkuz bulunmamalıdır. Usulcülere göre tenâkuz aralarını toplamak mümkün olmayacak şekilde iki eşit delilin çelişkili olmasıdır. ${ }^{43}$ Davada tenâkuz ise davacının davasını iptal edecek bir söz söylemesidir. Davacının ilk söylediği ile ikinci söylediği söz arasını toplamak mümkün değilse tenâkuz gerçekleşmiş olur. ${ }^{44}$ Davacının söylediği ifadelerde zitllğıın olması davanın dinlenilmesine engel teşkil etmektedir. Örneğin kişi bir evin vakıf olduğunu iddia etse, sonra o evin kendine veya başkasına ait olduğunu söylese, bu durumda zıtlık meydana gelmiş olur. Çünkü bir şeyin vakıf olması onun bir kişinin mülkiyetine ait olmasına engeldir. ${ }^{45} \mathrm{Bu}$ nedenle somut örnekte söylenilen ifadeler birbiriyle çelişmektedir. Mecelle'de, "Tenâkuz davacının davasında çelişkili ifade kullanmasıdır. Yani davasın batıl kılacak bir ifade kullanmasıdır. ${ }^{46}$ " şeklinde ifade edilmiştir.

\section{Dava Konusu İle İlgili Şartlar}

Davanın kâdı tarafından kabul edilmesi için dava konusunun gerekli dava şartlarını taşıması gerekmektedir. Dava konusu bakımından dava şartları sırasıyla şu şekildedir;

\section{a. Davada Maslahat Konusu}

İslam yargılama hukukunda fakihler dava şartı olarak ayrıca maslahatı zikretmemişlerdir. Maslahat fikıhta, faydayı celbetmek zararı defetmek manasına

41 Meydâni, Abdulğani b. Talip, el- Lübâb fi şerhi'l-kitâb, (thk. Muhammed Muhyiddin Abdu'l-Hamid), Mektebetu'l-İlmiyye, Lübnan, c. IV, s. 28; Mergınânî, Ebu'l-Hasen Burhânüddîn Ali b. Ebi Bekr, el- Hidâye fi şerhi Bidâyetü'l-mübtedî (thk. Talal Yusuf), Dâru İhyâ'u't-Turâs, Lübnan, yy.,ty., c. III, s. 155.

42 Serahsi, el-Mebsût, c.XVII, s. 96; Kâsânî, Bedâi, c. VIII, s. 417; İbn Nüceym, Zeynuddîn b. İbrahim b. Muhammed, el-Bahru'r-râ'ik şerhu Kenzi'd-dakâ'ik, Dâru'l-Kütübü'lİslamiyye, yy.,ty. s. 87; İbn Ferhûn, Tabsiratu'l-hukkâm, c. I, s. 136; Heytemî, Tuhfetu'lmuhtâç, c. X, s. 296; Şirbînî, Muğni'l-muhtâç, c. IV, s. 301; Kermî, Zeynuddîn Mer'i b. Yusuf, Gâyetu'l-müntehâ fì cem 'il- 'iknâ ve'l-müntehâ, Müessesetu Ğrâs, Kuveyt, 2007, c. III, s. 448; Buhutî, Mansur b. Yunus, Keşşâfu'l-kınâ ' ale metni 'l-İkn 'a, Dâru Kütübü'lİlmiyye, yy.,ty., c. IV, s. 203.

43 Tahânevî, Muhammed Ali, Mevsû'at keşşâfu'l-ıstılâhat, Mektebetü Lübnân, Lübnân, 1996, s. 1413.

44 Muhammed Rafet Osman, en-Nizâmu'l-kadâ, s. 235.

45 Molla Hüsrev, Muhammed b. Ferâmurz b. Ali Rûmî, Dureru'l-hukkâm fî şerhi gureri'lAhkâm, Dâru İhyâ'u Kütübü'l-Arabiyye, yy, ty, c. II, s. 430; Alaaddin Haskefî, Muhammed b. Ali b. Muhammed, Ed-Durru'l-muhtâr şerhu tenvîri'l-ebsâr, (thk. Abdulmun'im Halil İbrahim), Dâru Kütübü'l-İlmiyye, 2002, s. 478.

46 Mecelle Md. 1615.

Turkish Academic Research Review - Türk Akademik Araştırmalar Dergisi 
614 İslam Muhakeme Hukukunda Dava Şartları Ve Dava Harcının Bu Bağlamda Değerlendirilmesi

gelmektedir. ${ }^{47}$ Şeriat, maslahatı gerçekleştirmek ve zararı defetmek için vardır. Bu itibarla davada maslahat şeriatın emrettiği şeye denir. Şeriatın yasakladığı şeye ise zarar denir.

Fakihler zarar ve maslahata bağlanan kaideleri tayin etmişlerdir. Buna göre; “Kullanması haram olan şeyi almak da haramdır. ${ }^{48}$ ” kaidesine göre içki, domuz, vb. şeyleri almak haramdır. "Almanın haram olduğu şeyi vermek de haramdır. ${ }^{49}$ " kaidesine göre rüşvet, faiz gibi şeyleri almak haram olduğu gibi vermek de haramdır. Buradan netice olarak "Yapmanın haram olduğu şeyi istemek de haramdır. ${ }^{50}$ "' kaidesi çıkmaktadır.

Hanefiler davanın abes olmamasını şart koşmuşlardır. ${ }^{51}$ Abes, faydası ve menfaati olmayan bir iş yapmak demektir. Bu tarife itibarla abes, maslahatın tam tersidir. Mâlikîler ise davanın şeriat tarafından muteber ve faydalı sahih bir maksat için olmasını şart koşmuşlardır. ${ }^{52}$ Şâfiî ve Hanbeliler'de aynı görüşte olduklarına işaret etmektedirler. Malikiler davada maslahatın anlaşılması için genel bir kaide belirlemişler; maslahatı bu kaideye göre tespit etmişlerdir. Buna göre davada maslahat, ancak hasım ikrar ettiği zaman davacının fayda sağladığı bir dava konusu varsa gerçekleşmektedir. ${ }^{53}$

İslâm yargılama hukukunda fakihler dava şartı olarak ayrıca maslahatı zikretmemişlerdir. Fakat maslahat kavramının altına giren dava konusunun meşru ve davalıyı ilzam edebilecek nitelikte olmasını davanın sıhhat şartı olarak görmüşlerdir. Bu itibarlara göre davada maslahatın olması için dava konusunun meşru ve davalıyı ilzam edebilecek niteliğe sahip olması gerekmektedir.

Davacının dava açmakta maslahatı olması için dava konusu olan hakkın meşru bir hak olması şart koşulmuştur. Yani şeriatın saydığı veya caiz gördüğü şeylerden olmalıdır. Aynı zamanda bu hakkın kadâ ile şeriatte korunmaya alınmış olması gerekir. Çünkü kadâ, şeriatin belirlediği hükümleri sahipleri için gözetir,

47 Tûfi, Süleyman b. Abdullah, Şerhu muhtasari'r-ravda, Vuzâratu'ş-Şu'ûnu'l-İslâmiyye, Suudi Arabistan, 1419, c. III, s. 204.

48 el-Makdisî, Ebu Muhammed, Muvaffakuddin Abdullah b. Kudâme, el-Kâfí fi fikhi'lİmâm-ı Ahmed, Dâru Kütübü İlmiyye, 1. Bask1, 1994, c. I, s. 45.

49 Suyûtî, Celaleddin Abdurrahman b. Ebi Bekir, el- Eşbâh ve'n-nazâir, (thk. Bağdadî), Dâru'l-Kitâbu'l-Arabiyye, Beyrut, 1414, s. 150.

50 Suyûtî, el- Eşbâh ve'n-nazâir, s. 150.

51 İbn Âbidinzâde, Alaaddin Muhammed b. Abdulaziz, Kurratu 'uyûnu'l-ahyâr li tekmileti Reddi'l-Muhtâr ale ed-Durri'l-Muhtâr şerhu tenvîru'l-ebsâr, Dâru Se‘âde, yy.,ty, c. I, s. 381.

52 Karâfî, Ebu'l-Abbas Şihâbuddin Ahmed b. İdris, el- Furûk envêru'l-burûk fì Enve 'i’lfurûk, Âlemu'l-Kütüb, c. IV, s. 72.

53 İbn Ferhûn, Tabsiratu'l-hukkâm, c. I, s. 126; Karâfî, el- Furûk, c. IV, s. 72. 
onların hakkını başkalarının gasp etmesinden korur. ${ }^{54}$ İçki, domuz eti, faiz, kumar vb. şeyler gibi şeriatte caiz olmayan şeyler dava konusu yapılamaz. Çünkü şeriatte bunlar mütekavvim yani kıymetli mal değildirler. ${ }^{55}$

İslâm'nn meşru gördüğü her hak da dava yoluyla talep edilemez. Bu nedenle şeriatin caiz gördüğü fakat insanların onu yapmakla bağlayıcı olmadığı, insanların haklarında vücûbiyet ifade etmeyip yapmaları faziletli olan, karşıllı̆ıını da ahirette görecekleri şeyler hakkında dava kabul edilmez. Örneğin başkalarına iyilikte bulunmak, borç vermekten çekinmek, yakın akrabaya ziyarette bulunmak, vekâleti kabul etmek vb. haklar kişilerden diyaneten talep edilebilir. Fakat bu haklar kadâen talep edilemez. Yani bir kişi akrabalarını bana ziyarete gelmiyorlar diye mahkemeye veremez veya falanca bana borç para vermiyor diyerek kâdının huzuruna çıkamaz. Çünkü bu haklar her ne kadar şeriat tarafından diyaneten meşru olsa da kazâî olarak talebi mümkün kılınmamıştır. ${ }^{56}$

Davalıyı susturmak ve husumeti sonlandırmak için dava konusunun bağlayıcı kılacak nitelikte olması şart koşulur. Bu nedenle davanın yanlış kişiye yöneltilmesi veya iddia edilen şeyin husumet konusu olmadığı hallerde dava dinlenilmez. Dava hakkında hüküm verildiği zaman davalıyı bağlayıcı kılabilecek bir dava mevcut olmalıdır. ${ }^{57}$ Mecelle'de bu husus; "Dava sabit olduğu zaman davalının muhkem ve mülzem olması şart koşulur. Mesela bir kimse başka birine ödünç verse sonra başka bir kimse çıkı 'onu bana ödünç versin çünkü ben onun akrabasiyım.' dese davası sahih değildir. Yine biri başka birini bir meselede vekil tayin etse başka bir şahıs çılkp 'ben onun komşusuyum vekâleti bana versin ben vekâlete daha layığım.' dese yine davası sahih değildir. Çünkü bir kimse malını istediği kimseye ödünç verebilir ve işlerinde istediği kimseye vekâlet verebilir. Bu davalar ve benzerlerinde davalı hakkında hüküm verilmez. ${ }^{58}$ "şeklinde ifade edilmiştir.

Davacı davasını ispat ettikten sonra davalının ikrar, yemin ve yeminden çekinme yollarından biri ile bağlı olması ve bunun neticesinde hakkında hüküm verilmesi gerekir. Davalıyı ispat etme külfetine sokmayan ve hakkında hüküm

54 Kâsânî, Bedâi, c. VIII, s. 419; Zuhayli, Mevsû'âtu'l-fikhil-İslâmî, c. VI, s. 435; Tayyar, Fikhu'l-müyessere,c. VIII, s. 98.

55 Heyet, Mevsû'âtu'l-fikhiyyeti'l-kuveytiyye, Vuzâratu'l-Evkâf, Kuveyt, 2012, c. XX, s. 308; Tayyar, Flkhu'l-müyessere,c. VIII, s. 99.

56 Tayyar, Fikhu'l-müyessere, c. VIII, s. 99.

57 Haskefî, Ed-Durru'l-muhtâr, s. 510; Molla Hüsrev, Dureru'l-hukkâm, c. II, s. 330; İbn Ferhûn, Tabsiratu'l-hukkâm, c. I, s. 109.

58 Mecelle md. 1630.

Turkish Academic Research Review - Türk Akademik Araştırmalar Dergisi 
616 İslam Muhakeme Hukukunda Dava Şartları Ve Dava Harcının Bu Bağlamda Değerlendirilmesi

verilemeyecek olan davalar mülzem olmadıkları için sahih değildir. ${ }^{59}$ Örneğin davacı mahkemede hazır bulunan ve durumu inkâr eden davalının işinde vekil olduğunu iddia etse kabul edilmez. Çünkü davalı isterse o anda vekillikten azledebilir. Bir kimse batıl bir akdin hükümlerini yürürlüğe koymak için veya davalıdan sadaka talep etmek için dava açsa bu davalarda kabul edilmez. ${ }^{60}$ Çünkü bu hallerde de davalıyı bir şeyi yapmaya veya yapmamaya kazâî bir kararla zorunda bırakmak mümkün değildir.

Klasik fikıh kitaplarında davanın sıhhat şartları arasında maslahat şartı zikredilmemiştir. Fakat alimlerin dava konusunun meşru ve mülzem olmasını şart koşmalarından davada maslahatı gerekli gördükleri anlaşılmaktadır. Tüm bu bilgiler 1şığında davada sıhhat şartlarından birinin de maslahat olduğunu söylemek mümkündür.

\section{b. Dava Konusunun Akıl ve Âdet Bakımından Mümkün Olması}

Davanın dinlenmesi için dava konusunun akıl ve âdet bakımından mümkün bir şey olması gerekmektedir. Mümkün olmayan bir şeyin dava konusu yapılması halinde dava hâkim tarafından dinlenilmez. ${ }^{61}$ Söz gelimi bir kişinin kendinden yaşça büyük birinin oğlu olduğunu iddia etmesi veya fakir bir kimsenin asla kendinde bulunması mümkün olmayan bir miktarı zengin bir kimseye borç verdiğini iddia etmesi vb. gibi durumlar aklen ve âdeten muhal olmasından dolayı davanın sıhhatine engeldir. Bu davalar hâkim tarafından dinlenilmez. Fakat fakir bir kimse sattığ taşınmazın parasının zengin tarafından ödenmediğini veya zengin mirasçıdan kendisine miras kaldığını iddia ederse onun bu davası dinlenir. Şeref ve makam sahibi olmayan bir şahsın itibar ve makam sahibi olan bir adamı evinde hizmet etmesi için kiraladığını ve çalışmasını tamamlamadan ayrıldığını iddia etmesi de aklen ve âdeten mümkün değildir. Verilen örneklerdeki dava konuları, aklen ve

59 Ali Haydar, Dureru'l-hukkâm, c. IV, s. 209.

60 Zuhayli, Mevsû'âtu'l-fikhil-İslâmî, c. VI, s. 435; Ali Haydar, Dureru'l-hukkâm, c. IV, s. 209; İbn Nüceym, el-Bahru'r-râ'ik, c. VII, s. 192.

61 Ebu'l-Hâris, Muhammed Sidkı b. Ahmed el- Bornu el- Gazzî, Mevsû'atu'l-kavâ'idi'lfikhiyye, Müessesetu'r-Risâle, Lübnan-Beyrut, 2003, c. X, s. 884; Tayyâr, Fikhu'lmüyessere, c. VIII, s. 99; Muhammed Rafet Osman, Nizâmu'l-kadâ, s. 226; Zuhayli, Mevsû'âtu'l-fikhil-íslâmî, c. VI, s. 435; Haskefî, Ed-Durru'l-muhtâr, s. 510; Usâme b. Said el-Kahtân vd., Mevsû'atu'l-İcma ' fi'l-fikhi'l-İslâmî, Dâru'l-Fadîle, Riyad, 2012, c. III, s. 820; Şeyhzâde, Abdurrahman b. Muhammed b. Süleyman, Mecme 'u'l-enhur fì şerhi Mültekâ'l-ebhur, Dâru İhya'i-t-Turâsi'l-Arabî, c. II, s. 249: İbn Nüceym, el-Bahru'r-râ'ik, c. VII, s. 192: İbn Âbidinzâde, Kurratu 'uyûnu'l-ahyâr, c. I, s. 380. 
âdeten muhal olduğu için kâdı tarafindan dinlenilmez. ${ }^{62}$ Mecelle'de bu husus "Dava konusunun sübuta ihtimali olan şeylerden olması gerekir. Aklen ve âdeten varlı̆̆ imkânsız olan bir şeyi iddia etmek mesela 'Bir kimsenin kendisinden yaşça büyük veya nesebi malum olan bir kimse hakkinda benim oğlumdur.' demesi gibi. Bu durumda davası sahih değildir. ${ }^{63}$ " şeklinde ifade edilmiştir.

Netice olarak dava konusunda mülzem ve meşru olmasının zımnında maslahatın bulunması, aklen ve âdeten mümkün olan bir şey olması ve dava sonunda hakkında hüküm verilme ihtimali olan şeylerden olması şart koşulmuştur. $\mathrm{Bu}$ şartları sağlamayan bir dava konusu kâdı tarafından dinlenilmez.

\section{Dava Konusu Belli Olmalı}

Davadan maksat hüküm vermektir. Hüküm vermek ise davacı ve davalı arasındaki husumeti sonlandırmak içindir. Konusu belli olmayan bir davada hüküm vermek mümkün olmadığı için aradaki çekişmeyi sonlandırmak da imkânsızdır. İşte bu nedenle dava konusunun davada tam anlamıla tespit edilmesi, bilinebilir olması gerekir. ${ }^{64}$ Dava konusu malum olmadığı takdirde dava sahih olmaz. Davacı beyyine sunamaz. Davalı cevap vermeye zorlanamaz. İnkâr eden davalı yemin etmez. ${ }^{65} \mathrm{Bu}$ konu Mecelle'de: "Dava konusunun malum olması gerekir. Dava konusu meçhul olursa dava sahih olmaz. ${ }^{66}$ " şeklinde ifade edilmiştir.

Dava konusunun malum olması davacının, kâdının ve davalının zihninde dava konusunun ne olduğunu tam anlamıyla tasavvur ettirmesi demektir. ${ }^{67}$ Örneğin bir kimse 'Filan benim malımı helak etti.', 'Filan benim ortağımdı ancak bana ihanet etti.', 'Falanca kimse vefat etti ve bana mal vasiyet etti fakat ben ne kadar

62 Tayyar, Fıkhu'l-müyessere, c. VIII, s. 99; Zuhayli, Mevsû́'âtu'l-fikhil-İslâmî, c. VI, s. 435; Ali Haydar, Dureru'l-hukkâm , c. IV, s. 208; Muhammed Rafet Osman, Nizâmu'l-kadâ, s. 226.

63 Mecelle md. 1629

64 Meydânî, el-Lübab, c. IV, s. 26; Mergınânî, el-Hidâye, c. III, s. 153; Zuhayli, Mevsû'âtu'l-fikhil-İslâmî, c. VI, s. 435; Haddâdî, Ebu Bekir b. Ali b. Muhammed, elCevheretu'n-nîre, Hayriyye, 1322, c. II, s. 209; Muhammed Rafet Osman, Nizâmu'l-kadâ, s. 238; Bâbertî, Muhammed b. Muhammed b. Mahmud Ekmeleddin Ebu Abdullah, el'Inâye serhi'l-Hidâye, Dâru'l-Fikr, c. VIII, s. 157; Aynî, Ebu Muhammed Bedreddîn Mahmud b. Ahmed, el-Benâye şerhu'l-Hidâye, Dâru'l-Kütübü'l-İlmiyye, Lübnan, 2000, c. IX, s. 314; Salih b. Fevzân b. Abdullah Fevzân, Mulahhasu'l-fikhi, Dâru'l-Âsıme, Riyad, 1423, c. II, s. 633; Tayyar, Fıkhu'l-müyessere,c. VIII, s. 99; Kâsânî, Bedâi, c. VIII, s. 413.

65 Heyet, Mevsû'atu'l-fikhiyyeti'l-Kuveytiyye,c. XX, s. 298; Serahsî, el-Mebsût, c.XVII, s. 30; İbn Nüceym, el-Bahru'r-râ'ik, c. 192, s. 7; Âtâsi, Muhammed Hâlid, Şerhu'l-Mecelle, Dâru'l-Kütübü'l-İlmiyye, Beyrut, 2016, c. V, s. 12.

66 Mecelle md. 1619.

67 Heyet, Mevsû'atu'l-fikhiyyeti'l-Kuveytiyye, c. XX, s. 299.

Turkish Academic Research Review - Türk Akademik Araştırmalar Dergisi

https://dergipark.org.tr/tr/pub/tarr 
618 İslam Muhakeme Hukukunda Dava Şartları Ve Dava Harcının Bu Bağlamda Değerlendirilmesi

vasiyet ettiğini bilmiyorum' derse bu kimselerin davası sahih değildir. Çünkü dava konusu net bir şekilde ifade edilmemiştir. ${ }^{68}$

\section{Velâyetu'l-Kazâ}

İslâm yargılama hukukunda hangi tür davaya bakmakla görevli olan kâdı ve hangi yer/bölge kâdısının davaya bakacağını ifade etmek üzere velâyetu'l-kazâ tabiri kullanılmaktadır. İslâm'ın ilk dönemlerinde kâdılar sadece hukuk davalarına bakmakla mükellef iken sonraki dönemlerde ceza davalarına bakmakla da vazifelendirilmişlerdir. Yargı gücü, kâdıların yanında mezâlim mahkemeleri, şurta mahkemeleri, hisbe teşkilatı ve askerî mahkemeler tarafından da kullanılmıştır. ${ }^{69}$

Klasik fikıh doktrininde mahkemelerin görev ve yetkileri ile ilgili bağlayıcı bir hüküm olmamakla beraber kâdıların görevinin halife tarafından yer, zaman, mekan olarak sınırlandırılabileceği ifade edilmiştir. Nitekim İslâm yargılama hukuku tarihinde bunun örnekleri mevcuttur. ${ }^{70}$

Halife tarafından görevi, yer, zaman, mekan, konu, mezhep olarak sınırlandırılan bir kâdı görev sınırları dışındaki davalara bakamaz. Bakarsa verdiği hüküm geçersizdir. ${ }^{71}$ Mezhepler arasında bir beldede birden fazla görevli kâdı varsa davanın hangisine götürüleceği hususunda ihtilaf edilmiştir. ${ }^{72}$ Bazı fakihler davacının istediği kâdıya davasını götürebileceğini söylerken, bazısı ise bu hakkın davalıya ait olduğunu söyler. Buna göre davalının ikametgahında davanın açılması gerekmektedir. ${ }^{73}$ Birden fazla belde ve davaya bakabilecek birden fazla kâdı olduğu zaman ise davanın görüleceği yerin belirlenmesinde dava konusunun rol oynadığ görülmektedir. ${ }^{74}$ Örneğin dava konusu ayn olduğu zaman dava konusunun olduğu yerdeki kâdıya götürülmesinin gerekli olduğunu söyleyenler olduğu gibi davalının bulunduğu yerdeki kâdıya götürülmesi görüşünü benimseyenler de olmuştur. ${ }^{75}$ Kaynaklarda rastlamış olduğumuz mahkemelerin yetkilerinin, tarafların oturdukları yere ve dava konusuna göre belirlenmesi halleri bir beldede birden fazla kâdı olduğu

68 Ali Haydar, Dureru'l-hukkâm,c. IV, s. 184.

69 Atar, İslâm Yargllama Hukukunun Esaslarl, s. 105; Karaman, Anahatlartyla İslam Hukuku, Ensar Neşriyat, İstanbul, 2007, s. 240.

70 Aslan, Nasi, İslam Hukukunda Yargllama Etiği ve Illkeleri, Karahan Kitapevi, Ankara, 2019, s. 55.

71 Ali Haydar, Dureru'l-hukkâm, c. IV, s.599; Erturhan, Sabri, Temel Fıkıh Bilgileri, Hikmetevi Yayınları, İstanbul, 2018, s. 181.

72 Yâsîn, Nazariyyetu'd-d'avâ, s. 214.

73 Heyet, Mevsû'atu'l-fikhiyyeti'l-Kuveytiyye, c. XX, s. 278.

74 Yâsîn, Nazariyyetu'd-d'avâ, s. 218.

75 Heyet, Mevsû́ 'atu'l-fikhlyyeti'l-Kuveytiyye, c. XX, s. 280. 
zaman kargaşayı önlemekle ilgili durumlardır. Eğer görevli ve yetkili tek bir kâdı varsa bu konuda mezhepler arasında herhangi bir ihtilaf söz konusu değildir. ${ }^{76}$

Velâyetü'l-kazâ mutlak bir ifade ile davanın shhat şartları arasında sayılmasa da halife tarafından görev ve yetkisi belirlenmiş olan bir kâdının sadece kendi görev ve yetkisindeki davalara bakması davanın sıhhat şartları arasında sayılmıştır.

\section{Hüküm Meclisi İle İlgili Şartlar}

Davaların görüldüğü yere hüküm meclisi denir. Hüküm meclisinin diğer bir adı da mahkemedir. Mahkemelerin, insanların kolayca ulaşabileceği yerlerde ve rahatlıkla sığabileceği genişlikte olması gerekir. ${ }^{77}$ Kâdının davayı gördüğü yer, dükkan veya ev olsa bile üzerinde ittifak edilmiş, tüm davalarını orada gördüğü bir yer olmalıdır. Eğer dava böyle bir mecliste görülmezse davalı davaya cevap vermek zorunda değildir. ${ }^{78}$ Davaların mescitlerde görülmesi Cumhur-u ulemaya göre caizdir. Çünkü camiler ibadet yeridir. Kadâ da ibadet hükmündedir. Şâfiîler ise dava esnasında seslerin yükselmesi gibi sebeplerden dolayı camilerde dava görmenin mekruh olduğunu söylemişlerdir. İslâm'ın ilk dönemlerinde davalar mescitlerde veya evlerde görülüyorken sonraki dönemlerde davalara mescitlerde bakılması yasaklanarak davaların görülmesi için özel yerler tahsis edilmiştir ${ }^{79}$. İslâm yargılama hukukuna aleniyet ilkesi hakimdir. Bu nedenle davalar görülürken meclisin kapısı açık bırakılarak şeffaflık sağlanmaktaydı. Bazı istisnai ve özel durumlarda duruşmalar gizli yapılırdı. ${ }^{80}$ Genel açıdan İslâm hukukunda mahkeme kapısının özürsüz olarak kapatılması aleniyet açısından hoş görülmemiştir. ${ }^{81}$

Davanın kâdının âdeten bulunduğu mecliste olması şart koşulur. ${ }^{82}$ Davada asıl hedef çekişmenin bitirilmesi, kâdıdan hükmün ortaya çıkması, kâdının hükmedilen hükmü yürürlüğe sokmakla bağlayıcı kılmasıdır. Bu da ancak kâdının tarafları dinleyip, hükmü vermek için delilleri istemesi ile mümkün olabilir. İşte bu nedenle fukaha davayı tarif ederken kâdının önünde ifadesini tarife eklemiş̧tir.

\footnotetext{
Atar, İslâm Yargllama Hukukunun Esasları, s. 106.

Yâsîn, Nazariyyetu'd-d'avâ, s. 201.

7 Âtâsi, Şerhu'l-Mecelle,c. V, s. 10; Heyet, Mevsû'atu'l-fikhıyyeti'l-Kuveytiyye, c. XX, s. 278.

79 Heyet, Mevsû'atu'l-fikhlyyeti'l-Kuveytiyye, c. XXXVI, s. 142; Atar, İslam Yargllama Hukukunun Esaslarl, s. 167.

80 Atar, İslam Yargılama Hukukunun Esasları, s. 169; Yâsîn, Nazariyyetu'd-d'avâ, s. 204208.

81 Yâsîn, Nazariyyetu'd-d'avâ, s. 203.

82 Kâsânî, Bedâi, c. VIII, s. 415.
}

Turkish Academic Research Review - Türk Akademik Araştırmalar Dergisi https://dergipark.org.tr/tr/pub/tarr 
620 İslam Muhakeme Hukukunda Dava Şartları Ve Dava Harcının Bu Bağlamda Değerlendirilmesi

Fetva, görüş beyanı ise her mekanda caizdir. ${ }^{83}$ Dava kâdının meclisinden başka bir yerde dillendirilecek olsa bu davanın kâdı tarafından dinlenmemesi gerekir. ${ }^{84}$

\section{B. DAVA HARCI}

Resmi muâmeleler karşılığında hazineye girmek üzere alınan paraya "harç" denilmektedir. ${ }^{85}$ Günümüzde davaların görülebilmesi için dava açan kimsenin mutlaka gider avansını yatırmış olması gerekmektedir. Gider avansı yargılama esnasında yapılacak olan tebligat vb. masrafları karşılamak için konulmuştur. Günümüz hukukunda dava şartları arasında sayılmıştır. Bu avans davacı tarafından dava açılırken mahkeme veznesine yatırılmaktadır. İslâm hukukunda açılan davalar için günümüz hukukunda olduğu gibi masrafları karşılamak için bir ücret yatırılmasının gerekip gerekmediği ise mahkeme ile özdeşleşmiş kavramların en önemlisi olan kâdılar bağlamında ele alınabilir. İslâm yargısında mahkeme denilince akla kâdı gelir. Muhakeme usulüne dair hükümler kâdı üzerine bina edilerek verilir. Söz konusu durum sebebiyle kişilerin dava açarken belirli bir ücret verip vermeyeceği meselesi ancak kâdıların dava karşılığında bir ücret alıp almama durumu ile özdeşleştirilebilir. Bu nedenle dava açılırken davacı tarafından harç yatırılması meselesini kâdıların maaşı ve taraflardan ücret talep etmesi durumlarını ele alarak inceleyeceğiz. Bu bağlamda dava harcının dava şartları arasında değerlendirilip değerlendirilmediğini tespite çalışacağız.

İslâm hukukunda yargı, insanlar arasında çıkan uyuşmazlıkların çözüme kavuşması açısından çok büyük bir öneme sahiptir. Yargının temel unsurlarından biri de kâdılardır. Toplumda düzenin sağlanması ancak kazâî adaletin gerçekleşmesiyle mümkündür. Kazâî adaletin sağlanması ise yargı yoluna başvuran insanlar hakkında hüküm verecek olan kâdıların maddi ve manevi refah içinde olmalarıyla yakından ilgilidir. Bunun yanı sıra kadâ Allah Tealâ'nın emrettiği ve meşru kıldığı önemli bir dini vecibedir. $\mathrm{Bu}$ nedenle bazı İslâm alimleri kadâyı namaz gibi bir ibadet görerek Allah Teala’ya yakınlaşma vesilesi kabul etmişlerdir. Kadânın ibadet boyutunun da olması bu vecibeyi yerine getiren kâdıların icra ettikleri görev sebebiyle maaş almaları konusunda bir ihtilaf meydana getirmiştir. ${ }^{86}$ Buradan hareketle İslâm alimleri tarafından kâdıların maaş almasının caizliği tartışılmıştır. $\mathrm{Bu}$ nedenle meseleyi iki ayrı başlık altında değerlendirerek dava

83 Tayyar, Flkhu'l-müyessere,c. VII, s. 100.

84 Heyet, Mevsû'atu'l-fikhiyyeti'l-Kuveytiyye, c. XX, s. 285.

85 Erdoğan, Mehmet, Fıkıh ve Hukuk Terimleri Sözlüğü, Ensâr Yayınları, İstanbul, 2019, s. 180

86 Heyet, Mevsû' âtu'l-fikhıyyeti'l-kuveytiyye, c. XXXIII, s. 318. 
açılırken herhangi bir ücret yatırılmasının gerekli olup olmadığını davanın sıhhat şartları açısından ele alacağız.

\section{Kâdıların Devletten Maaş Almaları}

Hanefi mezhebinde kâdıların maaşa bağlanması durumu kâdının zengin veya fakir olmasına göre farklılık göstermektedir. Geçimini sağlayamayan kâdının görevi sebebiyle maaşa bağlanması konusunda herhangi bir ihtilaf söz konusu değildir. ${ }^{87} \mathrm{Bu}$ durumdaki kâdılara devlet başkanının beytülmâlden geçimlerini sağlamaları için yeterli miktarda maaş vermesinde herhangi bir problem yoktur. Kâdıların geçimlerini beytülmâlden sağlamaları onların mihnet ve sıkıntıya düşmemesi açısından büyük önem arz etmektedir. Çünkü bir kişinin kendine ve iyâline bakması onları geçindirmesi aklı meşgul eden şeylerdendir. ${ }^{88}$ Kâdılar ise bu meşguliyetlerden zihinleri en boş olması gereken kişilerdir. Onların hükümlerinde tarafsız olmaları, insanlar arasında adaletle hükmetmeleri insanlara karşı ihtiyaçsız olmaları ile sağlanabilir. Nitekim Hz. Peygamber Attâb bin Esid'i Mekke'ye vâli olarak atadığı zaman ona her sene 400 dirhem verilmesini emretmiştir. ${ }^{89}$ Söz konusu durum aynı zamanda kâdıların geçimi için ücret almasının meşruluğunu da göstermektedir. Ayrıca aynı uygulamayı Hz. Ömer'in Şam'da vali olan Muaz bin Cebel ve Ebu Ubeyde bin Cerrah'a mektup yazarak ehli ilimden olan kimseleri kadâ işlerine bakmaları için görevlendirmelerini ve onların kuvvetli olmaları için geçimlerinde ücretlerinin geniş tutulmasını emretmiştir. Söz konusu durumda Sahabenin uygulamasının aynı doğrultuda olduğu görülmektedir. Diğer taraftan Hanefi alimleri zengin olan kâdıların durumunda ihtilaf etmişlerdirler. Hanefilerden bir grup zengin olan kâdının ücret almasının caiz olmadığını söylerken bir grup ise ücret almasının caiz hatta faziletli olduğunu söylemişlerdir. ${ }^{90}$

Şafîi ve Malikî mezhebine göre kendi geçimini sağlayabilecek kadar bir gelire sahip olan bir kâdının maaş alması caiz değildir. ${ }^{91}$ Bunun yanı sıra Şafîîler geçimini sağlayamayan bir kâdının maaş almasının caiz olduğuna hükmetmişlerdir. ${ }^{92}$ Hanbeliler ise Kâdının kendi için çalışanları için ihtiyacı olsun

7 Heyet, Mevsû'âtu'l-fikhlyyeti'l-kuveytiyye, c. XXXIII, s. 318.

88 Kâsânî, Bedâi, c. VII, s. 13; Heyet, Mevsû'âtu'l-fikhıyyeti'l-kuveytiyye, c. XXXIII, s. 318; İbn Âbidîn, Muhammed Emin b. Ömer, Reddu'l-muhtâr ale'd-dürri'l-muhtâr, Dâru'lFikr, Beyrut, 1992, c. VI, s. 389.

89 Semnâni, Ravdatu'l-kudât, c. I, s. 86.

90 Semnâni, Ravdatu'l-kudat, c. I, s. 86.

91 İbn Ferhûn, Tabsiratu'l-hukkâm, c. I, s. 33.

92 En-Nevevi, Ebu Zekeriyya Muhyiddin Yahya b. Şeref, Ravdatu't-tâlibin ve 'umdetu'lmüftîn, (thk. Züheyr eş-Şaviş), Mektebetu'l-İslami, Beyrut, 1991, c. II, s. 137; Heyet, Mevsû'âtu'l-fikhiyyeti'l-kuveytiyye, c.XXXIII, s. 317.

Turkish Academic Research Review - Türk Akademik Araştırmalar Dergisi 
622 İslam Muhakeme Hukukunda Dava Şartları Ve Dava Harcının Bu Bağlamda Değerlendirilmesi

olmasın beytülmâlden maaş almasının caiz olduğunu söylemişlerdir. Bu görüşlerini Hz. Ömer'in kâdı Şurayh'a her ay 100 dirhem vermesine ve bunun yanı sıra vali olarak atadığı kâdılara ücret vermelerini zorunlu tutmasına dayandırmışlardır. Hanbelilerden bu görüşü fakir kâdıya tahsis edenlerde vardır. ${ }^{93}$

Kadâ işlerine vaktini ayıran kâdılarda ailesi ve bakmakla yükümlü oldukları kişilerin iâş̧esini sağlamak mecburiyetindedir. Bu görevi ifâ eden kâdılara geçimlerini sağlayabilecek miktarda bir ücret verilmezse rüşvet, haksız kazanç vb. kötü yollara tevessül etmelerine sebep olarak adaletin temel basamağının derinden sarsılmasına yol açılabilir. Bu nedenle kâdılara geçimlerini sağlayabilecekleri bir maaş verilmesi Osmanlı devletinin uygulamalarında da gözlemlenmiştir. ${ }^{94}$ Böylelikle kişilerin adaleti yerine getirmelerine büyük bir engel teşkil eden iâşe sıkıntısının önüne geçilerek hızlı bir şekilde adalet tesis edilmiştir.

\section{Kâdıların Taraflardan Ücret Talep Etmesi}

İslâm hukukunda kâdıların beytülmâlden maaş almaları hususunda bir sıkıntı olmadığı genel bir kanaattir. Bunun yanı sıra kâdının yargılama yapmak için taraflardan ücret talep etmesi ise tartışılmıştır. Hanefi, Şafii ve Maliki mezheplerine göre Hazreti Ömer'in müslüman bir kâdının verdiği karar üzerine ücret talep etmesinin uygun olmadığını söylemesinden dolayı kadâ üzerine ücret talep etmenin caiz olmadığına hükmetmişlerdir. ${ }^{95}$ Çünkü kadâ kişiyi Allah Teâlâ’ya yakınlaştırıcı olan namaz gibi bir ibadet olarak görülmüştür. Ancak burada dikkat edilecek husus kâdının insanlardan para istemesi hoş görülmemiş olmasıdır. ${ }^{96}$ Beytülmâlden ücret almasında ise belli şartlarla sakınca görülmemiştir. Nitekim yukarıda verilen örneklerde de maaş verildiği tespit edilmiştir. Bunun yanı sıra İbn Kudâme "kâdının geçim sıkıntısı varsa taraflara bana yargı ücretini getirene kadar aranızda hükmetmeyeceğim" demesinin caiz olmadığını, ancak bazı durumlarda caiz olabileceğini de söylemiştir. Hanbelilerin çoğunluğu ise caiz olduğu görüşünü tercih etmişlerdir. ${ }^{97}$ Mâverdî bu konuda ayrı bir hüküm getirerek belli şartlar altında örneğin; kâdının geçim sıkıntısı varsa ve icra ettiği kâdılık mesleği onun rızkını kazanmasına engel oluyorsa, muhakemeden önce iki tarafa da durumu bildirerek her

93 Buhutî, Keşşâfu'l-kınâ', c. VI, s. 290; Heyet, Mevsû'âtu'l-fikhıyyeti'l-kuveytiyye, c.XXXIII, s. 318.

94 Mehmet Akif Aydın, "Mahkeme", DİA, Ankara, 2003, c. XXVII, s. 343.

95 Sadru'ş-Şehîd, Şerhu edebi'l-kâdî, c.IV, s.105; Heyet, Mevsû' âtu'l-fikhıyyeti'l-kuveytiyye, c. XXXIII, s. 318.

96 Sadru'ş-Şehîd, Şerhu edebi'l-kâdî, c. IV, s. 104.

97 İbn Kudâme, Ebu Muhammed MuvaffakuddinAhmed b. Muhammed el-Makdisî, elMuğnî, Mektebetü’l-Kâhire, 1968, c. X, s. 35 
ikisinden almak kaydıyla ücret talep etmesinin caiz olduğunu söylemiştir. ${ }^{98} \mathrm{Bu}$ durumda mutlaka her iki taraftan alması ve İmamın izniyle bu işlemi yapmış olması gerekmektedir. Ayrıca aldığı ücret diğer hasımlardan alınan ücret kadar ve taraflara zarar vermeyecek bir miktar olması gerekmektedir. ${ }^{99}$ Mâverdî'nin bu görüşü belli şartlar altında kâdının davanın taraflarından ücret talep edebileceğini göstermektedir.

Sonuç olarak bazı alimler kâdının davanın taraflarından belli şartlar altında ücret talep etmesinin meşru olduğunu söyleseler de Hanbeli mezhebi dışındaki mezheplerce söz konusu durum uygun görülmemiştir.

\section{Kâdıların Durumu Bağlamında Dava Harcı}

Kadâ Allah Tealâ tarafından emredilen insanlar arasında adaletin sağlandığı önemli bir dini vecibedir. Bu nedenle büyük sorumluluğu yerine getiren kâdıların sırf bu iş sebebiyle maaş almalarının caizliği bile tartışılırken taraflardan yargılama yapılması için dava harcının talep edilmesi durumu akıllarda soru işareti meydana getirmektedir. İhtiyaç sahibi olan bir kâdının beytülmâlden maaş alması caiz görülmüş, hatta kâdı kendi giderlerini karşılayamıyorsa taraflardan yargılama yapmak için belli şartlar dahilinde ücret talep etmesine bazı alimler tarafından cevaz verilmektedir. Bunun yanı sıra bir kâdının devletten maaş almasını meşru gören mezhep olduğu gibi caiz görmeyen mezhepler de vardır. Osmanlı uygulamasına bakıldığı zamanda davalardan belli bir miktar harç alındığı gözlemlenmiştir. ${ }^{100}$

Tüm bu uygulamalar devletin dava karşılığında taraflardan ücret talep edilmesinin gerekli olduğuna hükmederek dava harcı alabileceğini göstermektedir. Ancak klasik fikıh kitaplarında davanın sıhhat şartları arasında tarafların dava harcı yatırmasının zorunlu olduğu zikredilmemiştir. Dava harcı talep edilmesi davanın sıhhat şartları arasında sayılsaydı günümüzde olduğu gibi harç yatırılmadan dava açılamazdı. Buradan hareketle tarafların dava harcı yatırmaları İslâm hukuku açısından davanın olmazsa olmaz bir şartı olarak belirlenmemiştir. Kaynakların ortaya koyduğu prensipler bağlamında dava harcı yatırılmasının davanın sıhhat şartları arasında sayılmadığı sonucunu ortaya koymaktadır. ${ }^{101}$

\section{Sonuç}

98 Heyet, Mevsû'âtu'l-fikhıyyeti'l-kuveytiyye, c. XXXIII, s. 318.

99 Heyet, Mevsû'âtu'l-fikhıyyeti'l-kuveytiyye, c. XXXIII, s. 318.

100 Aydın, "Mahkeme",c. XXVII, s. 343

101 Abdulkerim Zeydan, Nizâmu'l-kadâ fì şerî‘ati'l-İslâm, Müessesetü’r-Risale, Beyrut, 1989, s. 126.

Turkish Academic Research Review - Türk Akademik Araştırmalar Dergisi 
624 İslam Muhakeme Hukukunda Dava Şartları Ve Dava Harcının Bu Bağlamda Değerlendirilmesi

İslâm muhakeme hukukunda davaların görülüp karara bağlanması için belli usul kurallarının bulunması şart koşulmuştur. Bu kurallar davaların adaletli bir şekilde görülüp karara bağlanması için hayati önem taşımaktadır. Davaların kabul edilip karara bağlanması için tarafların, dava konusunun ve mahkemenin şu usul şartlarını taşıması gerektiği tespit edilmiştir;

- Kişilerin dava açmaları ve açtıkları davada tasarrufta bulunmaları için taraf ve dava ehliyetine sahip olmaları

- Kanuni temsilin zorunlu olduğu durumlar dışında herkes kendi davasını açıp takip edebilir. Davalarda kişilerin vekil tutma zorunluluğu yoktur. Ancak vekil aracıllğı ile takip edilen davalarda geçerli bir vekâletnamenin ibraz edilmesi gerekli görülmüş̧ür

- Açılan davanın gerçekten ilgili kişiye yöneltilmesi diğer bir adıyla kişilerin taraf sifatı bulunması

- Davanın belirli bir kişiye yöneltilmesi

- İstisnai haller dışında davalının dava esnasında hazır bulunması

- Davacının ifadelerinin kesin ve tutarlı olması

- Dava konusunun meşru ve mülzem olması bağlamında davada maslahat bulunması

- Dava konusunun aklen ve adeten mümkün olan bir şey olması

- Dava konusunun malum olmasi

- Görevi Halife tarafindan sınırlandırılmış bir kâdının sadece görev alanına giren dava konularına bakması,

- Davaların kâdıların meclisinde görülmesi.

Yukarıda maddeler halinde verilen taraflar, dava konusu ve mahkemeyle ilgili dava şartlarının davanın görülmesi için olmazsa olmaz şartlar olduğu sonucuna ulaşılmıştır. Ancak bu şartlar arasında klasik fikıh kitaplarında dava harcının yatırılması gibi bir dava şartına rastlanmamıştır. Bu bahis kâdılarla doğrudan bağlantılı olduğu için dava harcı konusu kâdıların maaşı ve ücret talep etme konularıyla bağdaştırılarak incelenmiştir. Bunun sonucunda fakir olan bir kâdının beytülmâlden maaş almasının tüm mezheplere göre caiz görüldüğü, zengin bir kâdının ise beytülmâlden maaş almasının Maliki, Şafii ve Hanefilerden bir kavle göre caiz görülmediği tespit edilmiştir. Kâdının yargılama yapmak için taraflardan ücret talep etmesinin Hanefi, Şafii ve Maliki mezheplerince caiz olmadığ görülmüş̧ür. Ancak çok zor durumda olan bir kâdının zaruret halinde taraflardan eşit miktarda ücret talep etmesinin Hanbeliler tarafindan caiz görüldüğü ifade edilmiştir. Bu bağlamda kâdânın dini bir vecibe olması sebebiyle İslâm hukukunda 
dava harcının alınması uygun görülmemiştir. Bununla birlikte devlet yargı giderlerini karşılayamayacak durumda olursa dava harcı alınmasına hükmedebilmesi açısından da açık bir kapı bırakılmıştır. İslâm hukukunda kişilerin dava açmak için dava harcı yatırmaları davanın sıhhat şartları arasında sayılmadığı gibi dava karşılığında ücret talep edilmemesinin de daha evla olduğu anlaşılmıştır.

\section{Kaynakça}

Abdulkerim Zeydan, Nizâmu'l-kadâ fî șerî‘ ati' '-İslâm, Müessesetü’r-Risale, Beyrut, 1989.

Abdullah b. Nâsır, Şurûtu etrâfi'd-d'avâ fi'l-fikhi ve nizâmi'l-murâfa 'ât, Nâif Arap Üniversitesi Eğitim Fakültesi, Riyad, 2006.

Alaaddin Haskefî, Muhammed b. Ali b. Muhammed, Ed-Durru'l-muhtâr şerhu tenvîri'l-ebsâr, (thk. Abdulmun'im Halil İbrahim), Dâru Kütübü'l-İlmiyye, 2002 ,

Ali Haydâr Hoca Emin Efendi, Dureru'l-hukkâm fi şerhi Mecelleti'l ahkâm, (terc. Fehmi Hüseyin), Dâru'l-Ceyl,1991.

Aslan, Nasi, İslam Hukukunda Yargllama Etiği ve İlkeleri, Karahan Kitapevi, Ankara, 2019.

Atar, İslam Yargılama Hukukunun Esasları, M.Ü. İlahiyat Fakültesi Yayınları, İstanbul, 2019.

Âtâsi, Muhammed Hâlid, Şerhu'l-Mecelle, Dâru'l-Kütübü'l-İlmiyye, Beyrut, 2016.

Aynî, Ebu Muhammed Bedreddîn Mahmud b. Ahmed, el-Benâye şerhu'l-Hidâye, Dâru'l-Kütübü'l-İlmiyye, Lübnan, 2000.

Bâbertî, Muhammed b. Muhammed b. Mahmud Ekmeleddin Ebu Abdullah, el'Inâye şerhi'l-Hidâye, Dâru'l-Fikr.

Beyâtî, Abdulgafûr Muhammed, el-Kavâ 'idu'l fikhiyye fi'l-kadâ, Dâru'l-Kütübü'lİlmiyye, Beyrut, 2015.

Buhutî, Mansur b. Yunus, Keşşâfu'l-kınâ' ale metni'l-İkn 'a, Dâru Kütübü'l-İlmiyye, yy.,ty..

Cessâs, Ebu Bekir Ahmed b. Ali er-Râzi, Şerhu edebu'l-kâdî, Amerika Üniversitesi, Kâhire, 1977.

Cüdey, Abdullah b. Yusuf b. İsa, Teysîru ilmi usuli'l-fikh, Müessesetu'r-Reyyân, Beyrut-Lübnan, 1997.

Ebu'l-Ferec, Abdurrahman b. Muhammed b. Ahmed b. Kudâme el- Makdisî, Şerhu'l-Kebîr ale metni 'l-Muknî, Dâru'l-Kütübü'l- Arabiyye, yy, ty,.

Ebu'l-Hâris, Muhammed Sidkı b. Ahmed el- Bornu el- Gazzî, Mevsû'atu'lkavâ 'idi'l-fikhiyye, Müessesetu'r-Risâle, Lübnan-Beyrut, 2003.

Turkish Academic Research Review - Türk Akademik Araştırmalar Dergisi

https://dergipark.org.tr/tr/pub/tarr 
626 İslam Muhakeme Hukukunda Dava Şartları Ve Dava Harcının Bu Bağlamda Değerlendirilmesi

Ebu'l-Hüseyn Müslim b. el-Haccâc Müslim, el-Câmi 'u's-sahîh, (thk. Muhammed Fuâd Abdulbâkî), Beyrut, Dâru İhyâi't-Turâs, ty..

el-Makdisî, Ebu Muhammed, Muvaffakuddin Abdullah b. Kudâme, el-Kâfí fi fikhi'lİmâm-ı Ahmed, Dâru Kütübü İlmiyye, 1. Baskı, 1994.

En-Nevevi, Ebu Zekeriyya Muhyiddin Yahya b. Şeref, Ravdatu't-tâlibin ve 'umdetu'l-müftîn, (thk. Züheyr eş-Şaviş), Mektebetu'l-İslami, Beyrut, 1991.

Erdoğan, Mehmet, Fıkıh ve Hukuk Terimleri Sözlüğ̈̈, Ensâr Yayınları, İstanbul, 2019.

Erturhan, Sabri, Temel Fıkıh Bilgileri, Hikmetevi Yayınları, İstanbul, 2018.

Fîrûzâbâdî, Ebu't-Tâhîr Mecduddîn Muhammed b. Yâkup, el-Kâmûsu'l-muhît, (thk. Muhammed Naim Araksûsi), Müessetu'r-Risâle, Beyrut, 2005.

Haddâdî, Ebu Bekir b. Ali b. Muhammed, el-Cevheretu'n-nîre, Hayriyye, 1322.

Heyet, Mevsû'âtu'l-fikhıyyeti'l-Kuveytiyye, Vuzâratu'l-Evkâf, Kuveyt, 2012.

Heytemî, Şihâbuddin Ahmed b. Hacer, Tuhfetu'l-muhtâç fi şerhi'l-Minhâç, Dâr-u İhyâ'ut-Turâs, Beyrut, ty,

İbn Âbidîn, Muhammed Emin b. Ömer, Reddu'l-muhtâr ale'd-dürri'l-muhtâr, Dâru'l-Fikr, Beyrut, 1992.

İbn Âbidinzâde, Alaaddin Muhammed b. Abdulaziz, Kurratu 'uyûnu'l-ahyâr li tekmileti Reddi'l-Muhtâr ale ed-Durri'l-Muhtâr şerhu tenvîru'l-ebsâr, Dâru Se'âde, yy., ty,

İbn Desûkî, Muhammed b. Ahmed, Hâşiyetu't-Desûkî ale'ş-şerhi'l-Kebîr, Dâru'lFikr, yy., ty..

İbn Ferhûn, İbrahim b. Muhammed, Tabsiratu'l-hukkâm fî usûli'l-akdıyye ve menehicu'l-ahkâm, Dâru 'Âlemi'l-Kütüb, Riyâd, ty,

İbn Hubeyra, el- Vezir Yahya b. Muhammed Avnuddîn Ebu'l-Muzaffer, İcmâ 'u'le'immeti'l-erba 'ati ve ihtilâfihim, (thk. Muhammed Hüseyin), Dâru'l-Ulâ, 2009.

İbn Kesîr, Ebu'l-Fedâ İsmail el-Kuraşî, Tefsîru'l-Kur-âni'l-Azîm, (thk. Muhammed Hüseyin Şemseddin), Dâru'l-Kütübü'l-İlmiyye, Beyrut, 1419.

İbn Kudâme, Ebu Muhammed Muvaffakuddin Ahmed b. Muhammed el-Makdisî, el- Muğnî, Mektebetü'l-Kâhire, 1968.

İbn Müflih, Muhammed b. Müflih, Ebu Abdullah, el- Furû, Menâr, Misır, 1339.

İbn Nüceym, Zeynuddîn b. İbrahim b. Muhammed, el-Bahru'r-râ'ik şerhu Kenzi'ddakâ'ik, Dâru'l-Kütübü'l-İslamiyye, yy.,ty..

İbn Seyda, Ebu'l-Hasan Ali b. İsmail, el-Muhassas, Dâru İhyâu't-Turâs, Beyrut, 1996.

Kahtân, Usâme b. Said vd., Mevsû'atu'l-icmâ'i fi’l-fikhi'l-İslâm, Dâru'l-Fadîle, Riyad, 2012.

Karâfî, Ebu'l-Abbas Şihâbuddin Ahmed b. İdris, el- Furûk envêru'l-burûk fî Enve 'i’l-furûk, Âlemu'l-Kütüb. 
Karaman, Hayrettin, Anahatlarıyla İslam Hukuku, Ensar Neşriyat, İstanbul, 2007.

Kâsânî, Alaaddin Ebu Bekir b. Mesud, Bedâ'i 'us'sanâ'i fì tertîbi'ş-şerâ 'i, (thk. Muhammed Têmir), Dâru'l-Hadis, Kahire.

Kermî, Zeynuddîn Mer'i b. Yusuf, Gâyetu'l-müntehâ fì cem 'il- 'iknâ ve'l-müntehâ, Müessesetu Ğırâs, Kuveyt, 2007.

Kutluboğa, Ebu'l-Fedâ Zeynuddin Kâsım, Hulâsatu'l-efkâr şerhu muhtasari'lmenâr, (thk. Hafiz Senâullah Zâhidî), Dâru İbni Hazm, yy., 2003.

Mehmet Akif Aydın, "Mahkeme”, DİA, Ankara, 2003.

Mergınânî, Ebu'l-Hasen Burhânüddîn Ali b. Ebi Bekr, el- Hidâye fi şerhi Bidâyetü'l-mübtedî (thk. Talal Yusuf), Dâru İhyâ'u't-Turâs, Lübnan, yy.,ty..

Meydâni, Abdulğani b. Talip, el- Lübâb fi şerhi'l-kitâb, (thk. Muhammed Muhyiddin Abdu'l-Hamid), Mektebetu'l-İlmiyye, Lübnan.

Molla Hüsrev, Muhammed b. Ferâmurz b. Ali Rûmî, Dureru'l-hukkâm fỉ şerhi gureri'l-Ahkâm, Dâru İhyâ'u Kütübü'l-Arabiyye, yy, ty,.

Muhammed Rafet Osman, Nizâmu'l-kadâ fi'l-fikhi 'l-İslâm, Dâru'l-Beyan, yy., 1994.

Nasr Ferid Vâsıl, Nazariyyetu'd-d'avâ ve'l-ispât fi'l-fikhi'l-İslâmi, Dâru'ş-Şurûk, Kahire, 2002.

Nizâmuddîn Belhî vd., Fetâvâyl hindiyye, Dâru'l-Fikr, Beyrut-Lübnan, 2009.

Râzi, Ebu Bekir Zeynuddîn ebu Abdullah b. Muhammmed, Muhtâru's-sihâh, (thk. Yusuf Şeyh Muhammed), Mektebutu'l-Asriyye, Beyrut, 1999.

Sadru'ş-Şehîd, Husameddin Ömer b. Abdulaziz, Şerhu edebi 'l-kâdî li' l-Hassâf, (nşr. İrşad Matbaası), Dâru'l-Arabiyye, Bağdad.

Salih b. Fevzân b. Abdullah Fevzân, Mulahhasu'l-fikhi, Dâru'l-Âsıme, Riyad, 1423.

Semnâni, Ebu'l-Kasım Ali b. Muhammed, Ravdatu'l-kudât ve tarîkun-necât, (thk. Salahaddin en-Nâhî), Müessesetu'r-Risâle, Beyrut, 1414.

Serahsi, Ahmed b. Ebi Sehl Şemsu'l-Eimme, el-Mebsut, Dâru'l-Mârife, Beyrut, 1993.

Suyûtî, Celaleddin Abdurrahman b. Ebi Bekir, el- Eşbâh ve'n-nazâir, (thk. Bağdadî), Dâru'l-Kitâbu'l-Arabiyye, Beyrut, 1414.

Şeyhzâde, Abdurrahman b. Muhammed b. Süleyman, Mecme 'u'l-enhur fì şerhi Mültekâ'l-ebhur, Dâru İhya'i-t-Turâsi'l-Arabî.

Şirbîni, Şemseddin Muhammed b. Ahmed el-Hatîp, Muğni'l-muhtâç ile Mâ'rifeti me'âni elfâzu'l-Minhâç, Dâru'l-Kütübü'l-İlmiyye, 1994.

Tahânevî, Muhammed Ali, Mevsû'at keşşâfu'l-lstılâhat, Mektebetü Lübnân, Lübnân, 1996.

Tarablûsî, Ebu'l-Hasan Alaaddin, Mu'înu'l-hukkâm fi me yeteraddedu beyne'lhasmeyni mine'l-ahkâm, Dâru'l-Fikr, yy., ty..

Tayyar, Abdullah b. Muhammed, Fikhu'l-müyessere, Medâru'l-Vatan, Riyad, 2011.

Turkish Academic Research Review - Türk Akademik Araştırmalar Dergisi

https://dergipark.org.tr/tr/pub/tarr 
628 İslam Muhakeme Hukukunda Dava Sartları Ve Dava Harcının Bu Bağlamda Değerlendirilmesi

Tûfi, Süleyman b. Abdullah, Şerhu muhtasari'r-ravda, Vuzâratu'ş-Şu'ûnu'lİslâmiyye, Suudi Arabistan, 1419.

Usâme b. Said el-Kahtân vd., Mevsû'atu'l-İcma ' fi'l-fikhi'l-İslâmî, Dâru'l-Fadîle, Riyad, 2012.

Yâsîn, Muhammed Naim, Nazariyeti't-d'avâ beyne Şeri'ati'l-İslamiyye, Dâru Alemi'l-Kütüb, Kingdom yay., Riyad, 2003.

Zuhayli, Vehbe, Mevsû 'atu'l-fikhi'l-İslâmî ve'l-kadâye'l-mu'âsıra, Dâru'l-Fikr, Beyrut, 2013. 